\title{
AN ANALYSIS OF THE GOOD FAITH BARGAINING PRACTICE IN THE TRADE UNION RECOGNITION PROCESS: REFORM OF THE MALAYSIAN TRADE UNION LEGAL FRAMEWORK
}

\author{
Siti Suraya Abd Razak * \\ Nik Ahmad Kamal Nik Mahmood **
}

\begin{abstract}
The trade union recognition process is a pre-requisite to the collective bargaining action of a trade union. The recognition is important to ascertain the competency of a trade union and the acceptance by the workers to represent them in the collective bargaining action with the employer. However, the ambiguities in the existing legislations on the trade union recognition process in Malaysia and the anti-union practices of the employer are currently depriving the workers of their rights to negotiate for better working conditions. The primary focus of the present work is to identify the weaknesses of the recognition legal framework and the anti-union practices of employers in the recognition process of trade unions. Secondly, is to critically analyse the good faith bargaining practice in other countries and its significance to the recognition process in Malaysia. To explore the anti-union tactics perpetrated by employers, semi-structured interviews have been conducted to analyse the trade unions' experience in their recognition claims. This research employed a qualitative approach as the instrument to study the good faith bargaining practices in the Australian and New Zealand labour law framework. The findings reveal that the good faith bargaining practices in Australia and New Zealand have improved the odds for trade unions to represent the workers in negotiating collective agreements. The study finally concludes that in order to reform the recognition process of trade unions in Malaysia, the good faith bargaining practice should be implemented in the nation's industrial relations law framework.
\end{abstract}

\footnotetext{
* Lecturer, Business and Finance Department, Sunway College Johor Bahru. Email: surayaa@sunway.edu.my.

** Professor, Department of Civil Law, Ahmad Ibrahim Kuliyyah of Laws, International Islamic University of Malaysia. Email: nahmad@iium.edu.my.
} 
Keywords: Trade Union, collective bargaining, recognition process, good faith bargaining practice, anti-union

\author{
SATU ANALISIS KEWAJIPAN NIAT BAIK DALAM \\ PERUNDINGAN SEMASA PROSES PENGIKTRAFAN \\ KESATUAN SEKERJA: MEREFORMASI PROSES \\ PENGIKTIRAFAN KESATUAN SEKERJA DI MALAYSIA
}

\begin{abstract}
ABSTRAK
Proses pengiktirafan kesatuan sekerja merupakan pra-syarat kepada proses perundingan kolektif kesatuan sekerja. Pengiktirafan adalah penting bagi mengenal pasti kelayakan kesatuan sekerja dan penerimaan pekerjapekerja untuk diwakili kesatuan sekerja di dalam proses perundingan kolektif dengan majikan. Walau bagaimanapun, ketidakpastian di dalam undang-undang pengiktirafan di Malaysia dan sikap anti-kesatuan dari majikan kini menyebabkan pekerja-pekerja kehilangan hak berunding bagi mendapatkan keadaan bekerja yang lebih baik. Fokus utama kajian ini adalah untuk mengenal pasti kelemahan di dalam kerangka kerja pengiktirafan kesatuan sekerja. Seterusnya, untuk menganalisis secara kritis prinsip kewajipan niat baik oleh negara-negara lain dan kepentingannya di dalam proses pengiktirafan di Malaysia. Menerusi kaedah temubual semi berstruktur, temubual dengan ahli kesatuan sekerja telah dilakukan bagi menganalisa pengalaman ahli kesatuan sekerja di dalam proses pengiktirafan. Kajian kualitatif digunakan untuk mengkaji kewajipan niat baik dalam proses perundingan seperti yang diamalkan di dalam kerangka kerja undang-undang pekerjaan di Australia dan New Zealand. Kajian ini mendapati bahawa peluang kesatuan sekerja di Australia dan New Zealand untuk berunding dengan majikan adalah lebih baik dengan adanya implementasi kewajipan niat baik dalam proses perundingan. Makalah ini menyimpulkan bahawa bagi mereformasi proses pengiktirafan kesatuan sekerja, kewajipan niat baik dalam perundingan mestilah dimasukkan di dalam kerangka kerja undang-undang perhubungan perusahaan di Malaysia.
\end{abstract}

Kata Kunci: Kesatuan Sekerja, perundingan kolektif, proses pengiktirafan, kewajipan niat baik, anti-kesatuan sekerja 


\section{INTRODUCTION}

Trade unions are currently facing a great challenge in obtaining recognition from employers so they can participate in collective bargaining actions. Recognition claim applications by trade unions are often rejected by employers or not ordered by the Minister on various grounds. This is because trade unions are often perceived by employers and the government as responsible for reducing a country's economic competitiveness in the global market. ${ }^{1}$ Available statistics have illustrated that the number of recognition claims successfully recognised by employers without any objections has decreased. ${ }^{2}$ In 2016, employers voluntarily recognised a trade union in only 2 out of 68 applications. A majority of the employers chose to reject the recognition claims made by the trade unions on various grounds, such as the competency of the trade union to represent their workers, the qualification of the workers to become members of the trade union, and because of improper procedures.

The unattractive environment in the trade union recognition system is one of the reasons for the fall in trade union density in Malaysia. ${ }^{3}$ The restrictive rules and regulations imposed by the trade union recognition legal framework, ${ }^{4}$ employers' hostility towards trade unions, and government policies has caused a decline in the density ${ }^{5}$ of the trade union. This decline has occurred despite an increase in the membership of registered trade unions in Malaysia. ${ }^{6}$ The anti-union practices of employers are visibly rampant when trade unions submit their recognition

${ }^{1}$ Nagiah Ramasamy, "Perceived Barriers to Trade Unionism in Malaysia". (PhD Thesis, University Putra Malaysia, 2010), 123-126.

22016 Statistic and Key Indicators, Department of Industrial Relations, Malaysia.

${ }^{3}$ Jaya Ganesan "A Review on Factors Contributing to Declining Trade Union Membership in Malaysia" International Journal of Advanced and Applied Sciences, 3(11) (2016), 93-98.

${ }^{4}$ Ong Sin Rua and et al, "Understanding the Declining of Trade Union Density: Literature Review and Conceptual Framework" Sains Humanika Vol.2, No. 2 (2014) :25-30.

${ }^{5}$ According to the ILO Report, the trade union density in Malaysia decline from $9,2 \%$ in 2014 to $8.8 \%$ in 2015 . In 2016, the trade union density remains constant at $8.8 \%$. (Trade Union Density Rate, ILO (2018).

${ }^{6}$ Jaya, "A Review on Factors Contributing” pp 65. 
applications as the employers are reluctant to bargain with their workers. Among employers' anti-union practices to avoid them from being successfully recognised are threats to dismiss the trade union members, dismissal of trade union members, restructuring the company resulting in the retrenchment of union members, transferring the workers to a subsidiary company where there is no work available, offering promotions to the trade union members resulting in their disqualification as members, forcing the members to resign their union membership, repeatedly filing for judicial reviews against the applications and establishing an in-house union with the motive of disqualifying the trade union.

In one instance, one employer known as Sabah Forest Industries has consistently filed for judicial reviews since 2003 on various grounds in its attempt to avoid the recognition claim made by the trade union. ${ }^{7}$ In another case, Nichicon Sdn. Bhd. deliberately refused to assist the Department of Industrial Relations ('DIR') in their investigation as part of the recognition process of the trade union. Despite numerous requests from the DIR for the employer to furnish a list of workers for the purpose of determining capacity, the employer did not take any action to assist the process. ${ }^{8}$ As a consequence of these anti-union practices, trade unions in Malaysia are having difficulties to bargain with employers.

It is alarming for the industrial relations climate in Malaysia when the record shows that the number of collective agreements that has been given cognisance in Malaysia is declining. The statistics of collective agreements in Malaysia are as provided in Table 1.

\footnotetext{
${ }^{7}$ International Trade Union Confederation "Report" ITUC Global Rights Index -Malaysia, http://www.refworld.org/docid/5799aa66c.html (accessed 1 January 1, 2017)

8 The employer, Nichicon Sdn. Bhd. refused to grant recognition to the Electronic Industry Workers' Union.
} 
Table 1 Statistics of Collective Agreements in Malaysia $(2015-2018)^{9}$

\begin{tabular}{|l|c|c|c|c|}
\hline \multicolumn{1}{|c|}{ Year } & 2015 & 2016 & 2017 & 2018 \\
\hline $\begin{array}{l}\text { Collective } \\
\text { Agreement that has } \\
\text { been given } \\
\text { cognisance by the } \\
\text { Industrial Court }\end{array}$ & 267 & 308 & 226 & 166 \\
\hline $\begin{array}{l}\text { The number of } \\
\text { workers covered } \\
\text { under the Collective } \\
\text { Agreement }\end{array}$ & 121,470 & 133,753 & 60,593 & 32,543 \\
\hline
\end{tabular}

Table 1 shows the declining number of collective agreements in Malaysia from 2015 to 2018 . There are only 166 collective agreements that have been accorded cognisance by the Industrial Court towards the end of 2018. Similarly, there is a significant decrease in the number of workers covered under collective agreements. From 60,593 workers in 2017 , the number has further reduced to only 32,543 workers covered under collective agreements in 2018. The decline of collective agreements and the decrease in the number of workers covered under these agreements depict a restrictive legal framework being imposed on trade unions in Malaysia. As a result, workers that are not covered under collective agreements are deprived of their rights to be represented by a trade union and are unable to improve their rights at the workplace.

The first aim of this study is to identify the weaknesses of the recognition legal framework and the anti-union practices of employers in the recognition process of trade unions. The second aim is to critically analyse the good faith bargaining practices in other countries and their significance to the recognition process in Malaysia.

92018 Statistic and Key Indicators, Department of Industrial Relations, Malaysia. 
This article uses a qualitative research method, namely a content analysis of journals, articles and various websites that address the concerns in the recognition process in Malaysia. A doctrinal analysis is applied to examine the relevant laws pertaining to the law on recognition of trade unions in Malaysia and other jurisdictions. For the fieldwork, the study collected data from interviews with employers, legal practitioner, an officer of the Department of Industrial Relations, an officer of the Department of Trade Union Affairs ('DTUA'), the Malaysian Trade Union Congress ('MTUC'), the Malaysian Employers Federation ('MEF') and trade unions in Malaysia on the issues and challenges in the trade union recognition process that have obstructed the trade union recognition system in Malaysia.

Furthermore, this article examines the recognition process in other jurisdictions. Australia and New Zealand are chosen for this study because of three factors; economic, political system and the states' compliance with the principles of the International Labour Organisation ('ILO'). These countries are high income countries and proven to be attractive to foreign investors by their high gross domestic product ('GDP'). Australia is a high-income nation in the Asia Pacific region with a GDP of USD1.32 trillion and a GDP growth rate of 2.9 percent from 2017 to 2018. The services sector contributed 68 percent of the Australian GDP in 2018. Australia had an estimated population of 24.9 million as of March 2017, a labour force participation rate of 62.2 percent, and a 5.2 percent unemployment rate. ${ }^{10}$ The GDP of New Zealand in 2018 was reported to be USD177 billion with a growth rate of 3.4 percent from 2017 to 2018 . The agriculture, fishing and forestry sectors contribute to an estimated USD130 billion of New Zealand's GDP. New Zealand has an estimated population of 4.7 million as of November 2018, a labour force participation rate of 67.8 percent, and a 5.2 percent unemployment rate. ${ }^{11}$ According to the prosperity theory, an increase in GDP allows trade unions to demand higher wages and benefits. ${ }^{12}$ The economic performances of Australia and New Zealand

10 “Australian Bureau of Statistics, 2018”Accessed on March 3,2018from http://www.abs.gov.au/AUSSTATS/abs@.nsf/mf/1345.0?opendocument

${ }^{11}$ Ibid.

12 Said F, Zakaria R.H and Said S.M. "The Determinants of Trade Union Membership Growth in Malaysia." International Journal of Economics, Management and Accounting (10) 2 (2002). 
demonstrate that the implementation of good faith bargaining principles in their trade union legal frameworks contributes to a high economic performance over time.

Politically, the governmental systems in these countries are similar to the Malaysian government system. This can be observed by similar applications of parliamentary democracy practices and the constitutional monarchies in these countries. These countries have also ratified ILO Convention No. 98 and have performed their obligation to provide a legal framework for collective bargaining action between the trade union and the employer. These countries are relevant to this study as they have demonstrated to be exemplary models for the recognition process of trade unions.

This article starts by explaining the concept of trade unions and the significance of the recognition process in the collective bargaining process of trade unions in Malaysia. The relevant law and practices in the trade union recognition in Malaysia will be scrutinised to highlight the anti-union practices by employers that surface due to the weaknesses that exist in the current national recognition system. Next, the article analyses the principles of good faith bargaining and its effectiveness in the collective bargaining frameworks of Australia and New Zealand. From here, an analysis of good faith bargaining practices in the trade union recognition process to reform the Malaysian trade union legal framework is made. Finally, this work is concluded with an answer to the main question i.e. whether good faith bargaining practices should be implemented in the recognition process of trade unions in Malaysia, and a suggestion is made to reform the recognition system.

\section{THE CONCEPT OF TRADE UNIONS AND RECOGNITION}

Before analysing the suitability of good faith bargaining practices in the Malaysian trade union legal framework, it is prudent to explain the concept of trade unions and the role of the recognition process in the collective bargaining framework. A trade union is defined as an organised association of workers in a trade, group of trades, or 
profession, formed to protect and further their rights and interests. ${ }^{13}$ The ILO defines a trade union as a workers' organisation constituted for the purpose of furthering and defending the interests of workers and to regulate the employment relationship through the direct process of collective bargaining with management. ${ }^{14}$ In Malaysia, the definition of a trade union is provided under the Industrial Relations Act 1967 ('IRA $1967^{\prime}$ ) to mean a trade union that is registered under any law relating to the registration of trade unions in Malaysia. ${ }^{15}$

Dawkins stated that there are three factors which attract workers to join a trade union. The first one is to improve wages and benefits. The second reason is to ensure their rights as workers are protected. Social reasons make up the third motive. ${ }^{16}$ From the perspective of Maimunah, workers become part of a trade union because of increased wages and benefits, job security, protection against unfair treatment, cooperation with fellow workers, and peer pressure. ${ }^{17} \mathrm{~A}$ trade union will be given a set of rights and responsibilities once the trade union is registered with the government. Among the rights given to the trade union are the right to take industrial action to protect the members, for example to call for a strike and picket to show their dissatisfaction to the employers. A registered trade union and its members will be immune from any suit or other legal proceedings in respect of any tortious act in any civil court. In some countries, the trade union is even immune from any criminal prosecution. Apart from that, the trade union has the right to negotiate with the employer to represent their workers in the form of a collective bargaining action. In Malaysia, a registered trade union is provided rights and immunities in order to perform its role. The rights of trade unions in

13 "Trade Union" Oxford Dictionary. Accessed September 10,2016 https://en.oxforddictionaries.com/definition/trade_union

14 "Trade Unions Labour Relations" Accessed November 20, 2018 https://www.ilo.org/global/topics/trade unions-labour-relations/lang-en/index.htm

15 'Trade Union' refers to the registered trade union as defined under Section 2(a) of the Trade Unions Act 1959.

16 Cedric Dawkins. "Beyond Wages and Working Conditions: A Conceptualization of Labor Union Social Responsibility." Journal of Business Ethics 95, no. 1 (2009): 129-43. doi:10.1007/s10551-009-0342-3.

${ }^{17}$ Maimunah Aminuddin, Malaysian Industrial Relations \& Employment Law. (Shah Alam, Selangor: McGraw-Hill (Malaysia) SdnBhd, 2016), 30. 
Malaysia can be found under the Trade Union Act 1959 ('TUA 1959') and the IRA 1967.

A trade union plays a crucial role in the industrial relations sphere. It's most important function is to represent the employees in expressing their demands to the employers for better employment contracts. Among the rights given to the trade union, the right to collective bargaining is the most significant. A collective bargaining action consists of a negotiation process between the employer on one side and the organised workers on another with the intention to determine working conditions and fair wages for the workers. ${ }^{18} \mathrm{An}$ effective collective bargaining process combined with a strong freedom of association in the state system is vital in securing a successful collective agreement between the trade union and the employer. ${ }^{19}$

As a member of the ILO, Malaysia recognises the establishment of trade unions to represent the interests of employees. The ratification of the ILO Convention on Right to Organise and Collective Bargaining No. 98 ('ILO Convention No. 98') by the government in 1961 has established the statutory right of the trade union to engage in collective bargaining action with the employer. However, the enjoyment of the right to collective bargaining is not straightforward as Section 13 of the IRA 1967 places a limitation on the trade union where the trade union of workers will only have the right to negotiate with the employer after obtaining recognition.

A trade union is subjected to a recognition process before a collective bargaining action can be exercised. The process of trade union recognition (the recognition process) is defined as a process in which the trade union obtains the support of a majority of the employees in the particular scope of work. ${ }^{20}$ Some scholars define the recognition process as a process that requires the employer's recognition ${ }^{21}$ or employer's

18 Jean Boivin, "Collective Bargaining" https://www.thecanadianencyclopedia.ca/en/article/collective-bargaining accessed January 24, 2019.

${ }^{19}$ Sharifah Suhana Ahmad. Industrial Relations Law in Malaysia: Cases and Materials. (University of Malaya Press, 2012), 123.

${ }^{20}$ Ibid.

${ }^{21}$ Ratna Sen. Industrial Relations- Text and Cases (New Delhi: Macmillan Publishers India Pvt ltd, 2009), 480. 
acceptance of the trade union to represent the employees in the collective bargaining action. ${ }^{22}$ During the recognition process, the competency of the trade union is determined through a majority vote of the workers of that particular group either by way of secret ballot or card-check mechanism. In some jurisdictions, employer's recognition is a prerequisite to collective bargaining. The absence of employer's recognition and majority support from the employees for the trade union will disqualify the trade union from negotiating with the employer for a collective agreement. The process of trade union recognition is a mechanism to solve the issue of trade union multiplication during the collective bargaining action with the employer and to prevent the 'divide and conquer' tactics of the employer. ${ }^{23}$

\section{UNFAIR PRACTICES IN THE TRADE UNION RECOGNITION}

The current practice in the recognition process under the IRA 1967 requires a trade union that wishes to represent a group of workers to fulfil two conditions. First, the union needs to obtain the employer's recognition and second, they are to prove that they are competent to represent the interests of the workers in that group. ${ }^{24}$ The procedure stipulates that upon the submission of the recognition claim, the employer can choose either to voluntarily recognise the trade union ${ }^{25}$, or to refuse the recognition claim within 21 days. ${ }^{26}$ In a situation where the employer refuses to recognise or ignore the recognition claim, the trade union can make a report to the Director General of Industrial Relations ('DGIR') to decide the competency of the trade union. ${ }^{27}$ It is observed that the 21-day maximum period given to the employer to provide feedback to the trade union is unnecessary as it will only delay the recognition process. If the employer doesn't provide a reply to the recognition claim, the trade union

\footnotetext{
22 Aminuddin, Maimunah. Employment Law Manual for Practitioners. (Malaysia: CLJ Publ., 2013), 15.

${ }^{23}$ Bernard D. Meltzer, \& S. D. Henderson, Labour Law, (Little, Brown \& Co, 1985), 830.

${ }^{24}$ Industrial Relations Act 1967, Section 9(1) .

${ }^{25}$ Section 9(3)(a) of Industrial Relations Act 1967.

${ }^{26}$ Section 9(3) (b) of Industrial Relations Act 1967.

${ }^{27}$ Section 9(4) of Industrial Relations Act 1967.
} 
has to wait for 21 days before it can proceed to lodge a complaint to the DGIR.

The DGIR is given the power to refer the case to the Director General of Trade Unions ('DGTU') to conduct a competency check on the trade union by examining the similarity of the industry, trade or occupation of the trade union with the job scope of the group of workers that the trade union wishes to represent ${ }^{28}$ Proving the competency of the trade union to represent the workers is a challenging task. The wide discretion given to the DGTU in checking for the 'similarity of trades, occupations and industries' is questioned by the trade unions as the DGTU are not industry experts, and thus not capable to have a final say on the competency of the trade union. ${ }^{29}$ In some recognition claims, the scope of representation in the industry by the trade union is limited by the DGTU due to economic reasons. ${ }^{30}$ It is the intention of the Malaysian government to limit the movement of trade unions and to prevent omnibus unions from being formed given the Malaysian government's experience with the communist movement. ${ }^{31}$

Anti-union tactics by the employer are also evident in the competency check of a trade union. In one case, a trade union submitted a recognition claim to the employer to represent electronic workers. The trade union was told that the employer had given an order to the workers to stop the production line for all electronic components and to hide all materials relating to the production of the electronic components. The trade union was later declared as not competent to represent the workers. ${ }^{32}$ As the employer is in control of the business, the employer can easily manipulate the DGTU's investigation to determine competency. Judicial review applications have also been applied by employers on the

${ }^{28}$ Section 9(4b)(b) of Industrial Relations Act 1967.

${ }^{29}$ Siti Suraya and Nik Ahmad Kamal "Trade Union Recognition in Malaysia: Legal Issues", UUMJLS Vol.9, (2018).

30 Malaysian government in its reply to the ILO report on the Electronic Industry Workers Union's recognition claim, stated that the action of allowing the electronic workers to be represented by the EIWU 'would create a disincentive for foreign investors'. ILO Official Bulletin Series 13, 63(2)(1980). ${ }^{31}$ Siti Suraya and Nik Ahmad Kamal "Ideology and Trade Union Movement in Malaysia", 1 MLJ Ixxxi.

${ }^{32}$ Interview by Author with the Leader of National Union of Electronic Workers (South), Johor on $19^{\text {th }}$ October 2018. 
competency issue such as in the case of Minister of Human Resources, Malaysia v Diamet Klang (M) Sdn Bhd and another appeal ${ }^{33}$, where the National Union of Transport Equipment and Allied Industries Workers sought to represent the workers of Diamet (Klang) Malaysia Sdn. Bhd. Diamet contended that the trade union was not competent to represent its workers as the employer was only a manufacturer of components and sub-components and that only $46 \%$ were sub-components which could be used in the automotive industry and that the majority were not meant for the automotive industry.

A provision in the IRA 1967 also requires that the workers do not fall under the managerial, executive, and confidential capacities of the employer's organisation ('MECS capacities') to prove that they are eligible for the secret ballot procedure and indirectly to become members of the trade union. ${ }^{34}$ An unfair practice by the employer can be seen where the employer resorts to disqualify the workers by restructuring or redefining their job positions. The issue lies within the absence of a standard interpretation or a guideline to determine the scope of work for workers who hold the MECS capacities. This situation therefore provides a path for the employer to file a judicial review so that the workers are not eligible for voting in the secret ballot. For instance, in the case of Sabah Forest Industries Sdn. Bhd. v The Honourable Minister of Human Resources Malaysia \& Anor. ${ }^{35}$

An application for a judicial review was made by the employer to quash the decision of the Minister in deciding the eligibility of the workers to be represented by Kesatuan Pekerja-Pekerja Industri Perkayuan Sabah. The employer challenged the Minister's decision in declaring that 139 of the workers under the supervisory category and 15 of the workers under the human resource division belonged under the MECS capacities. In addition, the DIR officer reported that some employers deliberately delay the submission of Form B (the name list of the workers) to the DIR office to slow down the recognition process. The employer would only take action to submit Form B after several

\footnotetext{
33 [2015] 6 CLJ 181.

${ }^{34}$ Section 9(1) of the Industrial Relations Act 1967.

35 [2018] 1 MLJ 277.
} 
reminders had been made by the DIR officer. ${ }^{36}$ It has become a practice for employers to delay the submission of the name list as there is no limitation period on when the employer should submit the name list to the DGIR.

A secret ballot is conducted by the DGIR to determine the majority support of the workers for the trade union. ${ }^{37}$ The secret ballot result is to be brought to the Ministry of Human Resource ('the Minister') for the Minister to decide on the recognition claim by the trade union. ${ }^{38}$ The decision of the Minister is final and shall not be questioned in any court. ${ }^{39}$ There is also a weakness identified in the secret ballot process that contributes to the unfair practices in the recognition system. The current practice in the recognition of trade unions, which is silent on the place to conduct the secret ballot, has caused the employer to use this opportunity to not allow the secret ballot to be conducted at the employer's premises. Issues also arise if the secret ballot is conducted at the employer's premises. From the findings of one interview conducted with a trade union member, the workers reported to the trade union that they had been intimidated by the employer during the voting process as the employer was in control of the premises. ${ }^{40}$ Besides that, the use of the word 'as soon as' in the provision ${ }^{41}$ has caused a delay as in some cases, the trade union has to wait for an indefinite period for the result to be released from the DGIR.

The above discussions show that judicial review applications have been constantly filed by employers to prevent the trade unions from successfully representing the workers. The uncertainties of the provisions in the IRA 1967 on the trade union recognition process have provided a stage for the employer to challenge the Minister's decision that is against

\footnotetext{
${ }^{36}$ Interview by Author with officer from Department of Industrial Relations, Putrajaya on $13^{\text {th }}$ November 2017.

${ }^{37}$ Section 9(4a)(b) of Industrial Relations Act 1967.

${ }^{38}$ Section 9(5) of Industrial Relations Act 1967.

${ }^{39}$ Section 9(6) of Industrial Relations Act 1967.

${ }^{40}$ In the interview with the Leader of National Union of Electronic Workers (South) on $19^{\text {th }}$ October 2018, the respondent claimed that in one of the secret ballots, 'the employer positioned a bodyguard at each corner of the factory to frighten the workers from voting'.

${ }^{41}$ Regulation 12 of the Industrial Relations Regulations 2009.
} 
him. The employer, with a good source of fund and expertise, will use this opportunity to prevent collective bargaining with the trade union. According to one trade union leader, it takes around one to two years for each recognition claim made by their trade union to be completed. ${ }^{42}$ The trade union has to go through the complex process of recognition and attend the judicial review cases with limited funds and members in order for the trade union to be recognised.

Therefore, in order to reform the trade union movement in Malaysia, the employer's anti-union practices in the trade union recognition process must be curbed. One of the ways to prevent these practices is by incorporating a principle known as good faith bargaining in the trade union recognition legal framework. Good faith bargaining promotes the principles of fairness and sincerity between the employer and the trade union in the collective bargaining process. Thus the following part will examine the good faith bargaining principles practiced in other countries and analyse how these practices would be suitable in the Malaysian context.

\section{GOOD FAITH BARGAINING PRACTICE IN AUSTRALIA AND NEW ZEALAND}

\section{Australia}

A compulsory arbitration and conciliation system that was introduced previously under the Paul Keating administration had stifled the trade union movement in Australia. The Workplace Relations Act 1996 had facilitated the employers to commit anti-union tactics especially in the collective bargaining process with the trade unions. ${ }^{43}$ This practice was later wiped out by the introduction of the Fair Work Act 2009 ('FWA 2009') under Kevin Rudd's administration. In Australia, the representative of the workers in the process of collective bargaining is

42 Interview by Author with the Leader of National Union of Workers in Support and Allied Services, Ipoh, Perak on $24^{\text {th }}$ August 2018.

${ }^{43}$ The example of anti-union tactics elements in the Act are first, by promoting an individual agreement between the employer and the worker instead of a collective agreement. Secondly, by a restrictive freedom of association clause and thirdly, by curtailing the powers of the commission members to deal with the recognition issue. 
known as the bargaining representative, whereas the output of the collective bargaining between the employer and the workers is known as the enterprise agreement. The bargaining representative of the workers can be a trade union, lawyer, consultant or any individuals that the workers wish to represent them in the negotiation process.

The procedures for collective bargaining are set out in Parts 2-4 of the FWA 2009. Before the trade union can become the bargaining representative and conduct collective bargaining with the employer, it must first register with the Fair Work Commission. The trade union can be a successfully registered trade union if it fulfils the criteria provided under the Fair Work (Registered Organisation) Act 2009. ${ }^{44}$ Amongst the requirements in the said Act are that the applicant must be 'genuine', free of employer's influence and able to provide evidence that it has a minimum of 50 members. The collective bargaining process starts off with the employer's obligation to serve a notice to the workers to inform their right to be represented by a bargaining representative, 14 days ${ }^{45}$ after either the employer agrees to bargain, or initiates to bargain for the agreement, or low paid authorisation or a scope order, or there is a majority support declaration by the workers for the agreement. ${ }^{46}$ Thereafter, the workers will be given two options, either to be represented by an individual or by a trade union of their choosing.

There is no formal recognition process of a trade union in Australia as the system applies the 'Default Approach' in setting out the bargaining representative for the workers. The trade union that is eligible to be a bargaining representative of the workers is the trade union of which the workers have become members. The workers can be represented by a trade union if the workers fulfil two requirements. First, the workers are members of the said trade union ${ }^{47}$ and second, the trade union is related to the work being performed under the enterprise agreement. ${ }^{48}$ Once these two conditions are proven, the trade union chosen by the workers

\footnotetext{
${ }^{44}$ Section 19 of Fair Work Act (Registered Organisation) Act 2009.

${ }^{45}$ Section 173(3), Division 3 of Fair Work Act 2009.

${ }^{46}$ Section 173 (2) (a)-(d) of Fair Work Act 2009.

${ }^{47}$ Section 176 (1) (a), Division 3 of Fair Work Act 2009.

${ }^{48}$ In Australia, the outcome of the collective bargaining is referred as enterprise agreement which is made between the employer, the worker and their bargaining representatives.
} 
will be the bargaining representative of the workers during the collective bargaining process. ${ }^{49}$ If the employer refuses to recognise the representative, then the employer will be subjected to a penalty. ${ }^{50}$

The main feature of FWA 2009 is the imposition of good faith bargaining practice with the objective of reviving the collectivism values in Australia's labour system. ${ }^{51}$ The inclusion of good faith bargaining practice in the FWA 2009 has compelled the employer to facilitate the collective bargaining process in good faith. This action in return benefits the trade union and the workers directly in protecting their rights at the workplace. The good faith bargaining practice is not to guarantee that the parties will reach consensus by way of collective agreement, instead it is incorporated to make sure that the collective bargaining process is conducted fairly and made with 'sincere effort' by all parties. ${ }^{52}$ The objectives of the good faith bargaining practice are clearly mentioned in the FWA 2009 as follows:

"The objects of this Part are:

(a) to provide a simple, flexible and fair framework that enables collective bargaining in good faith, particularly at the enterprise level, for enterprise agreements that deliver productivity benefits; and

(b) to enable the FWC to facilitate good faith bargaining and the making of enterprise agreements, including through:

(i) making bargaining orders; and

(ii) dealing with disputes where the bargaining representatives request assistance; and

(iii) ensuring that applications to the FWC for approval of enterprise agreements are dealt with without delay. ${ }^{, 53}$

In Australia's FWA 2009, the employer and the trade union are obliged under the good faith bargaining practice to refrain themselves from carrying out unfair conduct in the collective bargaining process.

\footnotetext{
${ }^{49}$ Section 179, Division 3 of Fair Work Act 2009.

${ }^{50}$ Ibid.

${ }^{51}$ Section 3 of the FWA 2009.

${ }^{52}$ Tim Capelin, Enterprise bargaining under the Fair Work Act Employment Law Bulletin (newsletter)/2011/Volume 17 No 5.

${ }^{53}$ Section 228 of the FWA 2009
} 
Good faith bargaining practices that have been clearly mentioned in the FWA 2009 are firstly, the parties must attend and participate in the meetings at reasonable times; second, the parties must reveal the required information to assist the bargaining process; third, the parties are to respond to proposals made by the other party in a timely manner; fourth, the parties must give genuine consideration to the proposal and give reasons for the response; fifth, the parties must refrain from capricious and unfair conduct that undermines the bargaining process; and lastly, to recognise the bargaining agent of the parties. ${ }^{54}$ Action can been taken against an employer that fails to perform its good faith bargaining practice obligations during the collective bargaining process. For instance, the Fair Work Commission can decide not to approve the collective agreement submitted by the employer in a case where the employer failed to advise the workers of their right to representation as required by the FWA 2009. ${ }^{55}$

Such an application can be seen in the case of Jocon $(S A) P / L^{56}$ where the Fair Work Commission declared the enterprise agreement as invalid because the trade union proved that the employer was not acting in good faith during the collective bargaining process. In this case, the employer ignored the trade union's right to represent the employer's workers as the 'default bargaining representative' of the workers. The employer had unfairly excluded the trade union from the negotiation process which is against the good faith practice under Section 228(e) of the FWA 2009.In the case of Australian Municipal, Administrative, Clerical and Services Union v Queensland Tertiary Admissions Centre Ltd, ${ }^{57}$ the Fair Work Commission held that the employer had breached its duty to adhere to good faith bargaining when they failed to recognise the trade union as the bargaining representative of its workers.

The employer had conducted the process unfairly by excluding the trade union from meetings and discussions of the enterprise agreement. While in Australasian Meat Industry Employees Union $v T \& R$ (Murray Bridge) Pty Ltd., it was decided by the court that the response given by the employer to the trade union during the negotiation process was

\footnotetext{
${ }^{54}$ Ibid

${ }^{55}$ Tim Capelin, Enterprise bargaining under the Fair Work Act pp 18

${ }^{56}$ [2011] FWA 6758

57 [2009] FWA 53.
} 
described by the court as "dismissive and very general" and did not assist the union in the collective bargaining process. ${ }^{58}$ Furthermore, Australian Services Union v NCR Australia Pty Ltd. held that an employer cannot unilaterally decide that it no longer wishes to continue bargaining for an agreement under the FWA 2009. ${ }^{59}$

\section{New Zealand}

The bargaining process in New Zealand was once characterised by the compulsory system of state arbitration in its Industrial Conciliation and Arbitration Act 1894 and the restrictive legislations governing the trade union movement under the Employment Contracts Act 1991. Under Helen Clark's Labour government, the system was changed by the introduction of the Employment Relations Act 2000 ('ERA 2000'). There are two types of collective bargaining in New Zealand under the ERA 2000, single-parties bargaining and multi-parties bargaining. Single-parties bargaining refers to the bargaining between just one employer and one union. Multi-parties bargaining refer to the bargaining between more than one union, employer or both.

In New Zealand, the recognition process is referred to as the initiation of collective bargaining in the ERA 2000. Part 5 of ERA 2000 describes the recognition process of a trade union in New Zealand. Either the trade union or the employer may initiate collective bargaining by sending a notice of initiation of collective bargaining if there is already an existing collective agreement in the previous bargaining process ${ }^{60}$ If there is no existing collective agreement, only the trade union can initiate the collective bargaining. ${ }^{61}$ In the case of a pre-existing collective agreement and in multi-parties bargaining, the trade union will send a notice to the employer showing their intention to start the collective bargaining for the workers in the employer's organisation. The notice must be in writing and signed by the trade union or the employer giving the notice or its duly authorised representative; it identifies the intended parties to the collective agreement and also identifies the coverage

\footnotetext{
58 [2010] FWA 87.

59 [2010] FWA 6257 (Commissioner Cambridge, 16/0810).

${ }^{60}$ Section 40(1) of the ERA 2000.

${ }^{61}$ Section 40(2) of the ERA 2000.
} 
clause. ${ }^{62}$ The next step is the employer must determine the coverage clause and its intended parties as soon as possible but not later than 10 days or 15 days depending on the circumstances. ${ }^{63}$

In a situation where one or more trade unions opted for single-parties bargaining with the employer, a secret ballot of union members must be held if more than one trade union is named as a party in the notice initiating bargaining. ${ }^{64}$ The result of the secret ballot of members is determined by a simple majority of members who are entitled to vote. ${ }^{65}$ The trade union that wins the majority of the votes may initiate bargaining with the employer in accordance with Section 42 of the ERA 2000 .

The good faith bargaining practice has been injected into the ERA 2000 and characterises its collective bargaining process. The aim of the good faith bargaining practice in the ERA 2000 is similar to the good faith bargaining practice under the FWA 2009, which is the negotiation does not necessarily require the parties to reach any final agreement ${ }^{66}$ but to ensure that the collective bargaining process is carried out in a fair and sincere manner by all parties. ${ }^{67}$

The good faith bargaining practice is expressly mentioned in the ERA $2000^{68}$ as follows:-

"(1) The duty of good faith in section 4 requires a union and an employer bargaining for a collective agreement to do, at least, the following things:

(a) the union and the employer must use their best endeavours to enter into an arrangement, as soon as possible after the initiation of bargaining, that sets out a process for conducting the bargaining in an effective and efficient manner; and

${ }^{62}$ Section 42 (2) of the ERA 2000.

${ }^{63}$ Section 43 of the ERA 2000.

64 "Collective Bargaining" Accessed on August 6, 2018 from https://www.employment.govt.nz/starting-employment/unions-and-

bargaining/collective-agreements/collective-bargaining/initiation-of-collectivebargaining/.

${ }^{65}$ Section 45 of the ERA 2000.

${ }^{66}$ Section 33 of the ERA 2000.

${ }^{67}$ Richard A. Epstein, Employment and Labor Law Reform in New Zealand, 33 Case W. Res. J. Int'l L. 361 (2001), 376.

${ }^{68}$ Section 32 of the ERA 2000. 
(b) the union and the employer must meet each other, from time to time, for the purposes of the bargaining; and

(c) the union and employer must consider and respond to proposals made by each other; and

(ca) [Repealed]

(d) the union and the employer-

(i) must recognise the role and authority of any person chosen by each to be its representative or advocate; and

(ii) must not (whether directly or indirectly) bargain about matters relating to terms and conditions of employment with persons whom the representative or advocate are acting for, unless the union and employer agree otherwise; and

(iii) must not undermine or do anything that is likely to undermine the bargaining or the authority of the other in the bargaining; and

(d) the union and employer must provide to each other, on request and in accordance with section 34, information that is reasonably necessary to support or substantiate claims or responses to claims made for the purposes of the bargaining."

The consequence of this provision can be seen in the initiation process of collective bargaining in New Zealand. The employer is not the party to determine the competency of the trade union to represent the workers, instead the workers are given the power to determine the trade union of their preference to represent them in the collective bargaining process with the employer.

Complaints concerning the breach of good faith bargaining obligations during the recognition process of trade unions in New Zealand can be seen in some cases. For instance, in the case of The New Zealand Public Service Association v Secretary for Justice, ${ }^{69}$ the Employment Relations Authority ${ }^{70}$ held that the decision made by the employer to unilaterally end the bargaining process was acting in breach

69 [2010] 11 NZEMPC WRC 54/90.

${ }^{70}$ It is an independent body set up under the ERA 2000 that helps to resolves employment relationship problems. 
of good faith. In the case of National Distribution Union $v$ Sawmill Services $L t d,{ }^{71}$ the employer's action in resisting the multi-employer collective employer agreement proposed by the trade union was held to be in breach of good faith. The Employer Relations Authority advised the employer to 'approach negotiations in open mind on the matter and properly consider arguments raised' and ordered the parties to resume their bargaining process and to properly consider proposals put forward by the other. Similarly, in the case of NZ Amalgamated Engineers Union Inc $v$ Carter Holt Harvey Ltd ${ }^{72}$, the Employment Court identified three actions made by the employer that had breached the good faith bargaining duty. First, when the employer failed to consult in a timely manner; second, when the employer insisted on consulting with the workers individually (rather than through the trade union which had the authority to represent the workers); and third, failing to disclose relevant material for the collective bargaining process.

With the introduction of the ERA 2000 to New Zealand's labour law framework, the trade unions' right to a fair and efficient collective bargaining has been restored. ${ }^{73}$ The application of good faith bargaining into the ERA 2000 has caused a slight increase of unionisation and collective bargaining coverage in New Zealand. ${ }^{74}$

\section{SUGGESTIONS AND RECOMMENDATIONS}

The co-operation between the employer and the trade union plays a crucial role in the collective bargaining process. From the above analysis, it is observed that bargaining in good faith is a new approach in industrial relations that has been practiced in highly developed countries. The introduction of good faith bargaining practice in Australia's FWA 2009 and New Zealand's ERA 2000 has improved the chances of workers to be represented by a trade union in the collective bargaining process and it has made the two countries' trade union recognition process as one of the

\footnotetext{
71 (unreported, AA 134/01, 17 Sep 2001).

72 (unreported, AC 53/03, 30 Augt 2002).

${ }^{73}$ Gordon Anderson, Transplanting Good Faith into New Zealand Labour Law: The Experience under the Employment Relations Act 2000 [2002] Mur UEJL 40.

${ }^{74}$ Ibid, pp 372.
} 
most established and efficient in the world. Therefore, following these steps, Malaysia should take the initiative to promote good faith bargaining principles in resolving issues between the trade union and workers. The inclusion of the good faith bargaining practices in the FWA 2009 has encouraged a good faith practice between the employer and the trade union in bargaining process unlike in Malaysia where the Code of Conduct for Industrial Harmony only serves as a guideline with no enforcement. Hence, with the inclusion of good faith bargaining practices in the IRA 1967, the authorities can penalise any party or parties that fail to perform their duty to act in a sincere manner and in good faith during the recognition process of trade unions.

Most importantly, the implementation of good faith bargaining practices is relevant to the Malaysian context as this action will close the door for the employer to exercise its anti-union tactics during the trade union recognition process. The application of good faith bargaining principles will allow the trade union to lodge a complaint to the authority in cases where the employer attempts or commits any action that can be proven to be unfair to the trade union.

Clear guidelines and interpretations of good faith bargaining principles must be set up for a clear application. It is recommended that the objectives of good faith bargaining principles to be included in the IRA 1967. The provisions should be as follows:-

"The duty of good faith requires the trade union and the employer bargaining for a collective agreement to do, at least, the following things in the recognition process:

(a) the trade union and the employer must use their best endeavours to ease the recognition process for conducting the bargaining in an effective and efficient manner; and

(b) the trade union and employer must respond as soon as possible to the requests or enquiries made by other parties, the DGIR, the DGTU and the Minister; and

(c) the employer must refrain from capricious or unfair conduct that undermines freedom of association or collective bargaining."

It is also proposed to include the provisions for breach of good faith bargaining principles during the recognition process in the IRA 1967. The provisions are as follows:-

"Breach of Good Faith Bargaining Principles 
(1) Upon the complaint that the parties in the recognition process have not met, or are not meeting, the good faith requirements, the DGIR may make an order directing any party to comply with the requirement under the recognition process.

(2) Any person who fails to comply with an order of the DGIR under subsection (1) shall be guilty of an offence and shall, on conviction, be liable to a fine not exceeding five thousand ringgit or to imprisonment for a term not exceeding one year or to both and a further fine of five hundred ringgit for every day during which such offence continues."

\section{CONCLUSION}

By drawing on the situation of the trade union recognition process in Malaysia, this paper has framed that the weakness found in the trade union recognition process is due to the inadequate provisions in the IRA 1967. This restrictive legislation is found to originate from the Malaysian government's security policy which was imposed on the trade union movement due to the severity of the communist attack in Malaya coupled with the economic policies of the government. It indeed appears that the trade unions and the workers are affected by these policies as they are currently struggling to exercise their rights to collective bargaining with the employers. This paper also found that the current legislations provide a path for employers to avoid negotiating with the trade unions. This has eventually become anti-union practices on the part of the employers once the trade unions submitted their recognition claims.

The data collected from interviews conducted with the respondents' show that employers have resorted to various anti-union tactics to prevent trade unions from exercising their right to collective bargaining. Examples of these tactics are rejecting the recognition claim without a proper reason, delaying the recognition claim result, repeatedly filing for a judicial review and intimidation of the workers during the balloting process. As a result of these unfair practices, trade union membership and the density of the trade union in Malaysia have been deteriorating each year. The good faith bargaining principles that have been implemented in the Australian and New Zealand labour law frameworks have brought about significant changes in the relationship between the employer, trade union and workers.

It is found that this good faith bargaining practice will eliminate antiunion tactics by the employer against the trade union and will guarantee a 
fair process of collective bargaining. Thus, this study stands for the notion that the IRA 1967 should be amended to implement good faith bargaining principles in order to reform the trade union recognition process in Malaysia. 